\title{
Physical activity during COVID-19 induced lockdown: recommendations
}

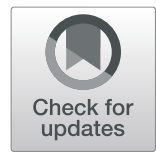

\author{
Eszter Füzéki ${ }^{*}$ (D, David A. Groneberg and Winfried Banzer
}

\begin{abstract}
Measures aiming at containing the Coronavirus disease 2019 (COVID-19) include isolation, social distancing, and quarantine. Quarantine and other lockdown instruments show promise in reducing the number of COVID-19 infections and deaths. It is reasonable to assume that lockdown leads to reduced levels of physical activity in the general population. Potential detrimental health effects of lockdown, such as psychological distress and physical inactivity induced maladaptations must be addressed. The current review summarizes harmful effects of limited physical activity on mental and physical health due to social distancing and quarantine and highlights the effects of simple physical activity regimes counteracting these detrimental effects, with a special emphasis on acute effects.
\end{abstract}

Keywords: Physical activity, Lockdown, Health

\section{Background}

The Coronavirus disease 2019 (COVID-19), caused by a novel coronavirus, SARS-CoV-2 (severe acute respiratory syndrome coronavirus-2) has reached pandemic dimension worldwide. In the absence of a preventive vaccine and specific pharmaceutical options, public health measures are essential to contain the spread of the virus. Successful strategies have already been identified; beyond strict hygienic rules these measures include isolation, social distancing, and quarantine. A rapid Cochrane systematic review, based primarily on simulation studies, indicates that quarantine, especially if combined with other measures, such as school closures, travel restrictions and social distancing might reduce the number of COVID-19 infections and deaths [1]. A report from China confirms these findings [2]. Mathematical modelling projecting potential scenarios for SARS-CoV-2 transmission in the future foresee that prolonged or intermittent social distancing may be necessary into 2022 [3].

\footnotetext{
* Correspondence: fuezeki@sport.uni-frankfurt.de

Division of Preventive and Sports Medicine, Institute of Occupational, Social and Environmental Medicine, Goethe University Frankfurt, Theodor-Stern-Kai 7, Haus 9B, 60590 Frankfurt am Main, Germany
}

According to a BBC News report, dated 07.04.2020 over 100 countries worldwide have implemented full or partial lockdown measures as of late March, affecting billions of citizens [4]. Severity of measures differ, but they all aim at limiting social contacts, which necessarily implies opportunities to move around.

While quarantine and social distancing measures seem indispensable as of now, possible detrimental social, psychological, health and economic consequences must also be considered. Psychological impact of quarantine can be wide-ranging, substantial and potentially sustained [5]. Symptoms include emotional disturbance, depression, stress, low mood, irritability, insomnia, post-traumatic stress symptoms and anxiety [5]. Little is known about the psychological effects of less rigorous, but prolonged measures of confinement.

The aim of the present article is 1) to review harmful effects of limited physical activity on mental and physical health due to social distancing and quarantine and 2) to highlight the effects of simple physical activity regimes, with a special emphasis on acute effects. We provide recommendations for evidence based physical activities that are feasible even in lockdown situations, and that hold promise to help patients cope with the situation.

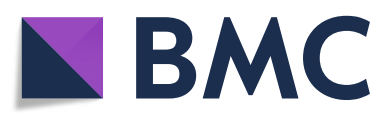

(c) The Author(s). 2020 Open Access This article is licensed under a Creative Commons Attribution 4.0 International License, which permits use, sharing, adaptation, distribution and reproduction in any medium or format, as long as you give appropriate credit to the original author(s) and the source, provide a link to the Creative Commons licence, and indicate if changes were made. The images or other third party material in this article are included in the article's Creative Commons licence, unless indicated otherwise in a credit line to the material. If material is not included in the article's Creative Commons licence and your intended use is not permitted by statutory regulation or exceeds the permitted use, you will need to obtain permission directly from the copyright holder. To view a copy of this licence, visit http://creativecommons.org/licenses/by/4.0/ The Creative Commons Public Domain Dedication waiver (http://creativecommons.org/publicdomain/zero/1.0/) applies to the data made available in this article, unless otherwise stated in a credit line to the data. 
This knowledge can build the base for physical activity counseling in COVID-19 lockdown times.

\section{Metabolic, vascular and musculoskeletal effects of reduced physical activity}

Current physical activity recommendations advise the general population to aim at performing at least 150300 min of moderate or $75-150$ min of vigorous physical activity a week (or a combination of these), and muscle strengthening activities at least twice a week [6]. It is however essential to emphasize that physical activity much below this level is also beneficial, and that evidence based health enhancing physical activity can come in many easily available shape or form [7].

It is reasonable to assume that lockdown measures have fundamentally changed work and transport related physical activities for a large proportion of the working population. With the closure of sports and fitness clubs as well as outdoor exercise facilities also leisure time activities might be affected, potentially leading to a further decline of already low levels of physical activity at the population level [8].

Step reduction studies, i.e. intervention studies in which participants are instructed to limit the number of steps taken, which might best mimic current situation for large parts of the general population under lockdown, shed light on the health effects of even relatively short periods of physical inactivity $[9,10]$.

The reduction of ambulatory activity from a relatively high (about 10.000 steps/day, which approximates recommended level of physical activity) to a low level (less than 2500 steps/day) for 14 days leads to metabolic maladaptations, such as increased intraabdominal and ectopic fat accumulation, hyperinsulinaemia even in young healthy adults $[9,10]$. Further, this short term reduced activity results in an up to $6.6 \% \mathrm{ml} / \mathrm{min} / \mathrm{kg}$ loss of cardiorespiratory fitness, and muscle atrophy in the lower extremities [9]. Fourteen days of step reduction in elderly participants induces detrimental alterations in glucose and insulin metabolism, impaired skeletal muscle protein synthesis, losses in muscle mass, as well as rise in inflammatory cytokines $[9,10]$.

Halving daily step count (from about 10.000 to 5.000) for just 5 days also led to a marked reduction in endothelial function at the popliteal but not brachial artery and a fivefold increase in endothelial microparticles in young healthy participants [11].

Importantly, resuming higher levels of ambulatory activities can reverse negative effects [9], and concomitant (even low intensity) resistant exercise (i.e. resistance exercise while ambulatory activity is kept reduced) can contribute to preservation of anabolic and insulin sensitivity [12]. This reversal, however, might be incomplete or require longer and more intensive activity periods in the elderly and chronically ill than in younger healthy adults $[9,10,13]$.

Taken together, even acute, short periods of reduced physical activity may have deleterious effects on many organs and systems, and these effects might be more pronounced and more challenging to reverse in certain more vulnerable populations, such as the chronically ill and the elderly.

\section{Acute and sustained effects of physical activity}

Regular moderate physical activity has wide reaching health benefits for people of all ages, sexes, races, health conditions and shapes, as shown in reduced morbidity and mortality rates, increased quality of life and independence in old age [6]. Physical fitness can also help reduce the risk of acute life threatening events [14, 15]. To maintain these effects sustained, optimally lifelong physical activity is required, since acute benefits are transient and dissipate over time, unless physical activity stimulus is repeated. However, knowledge about acute impact of single exercise bouts might facilitate the motivation and communication with patients to take up more activity now. The current crisis could potentially be a window of opportunity, a learning moment to initiate long-term activity.

\section{Acute metabolic and vascular effects of physical activity}

Physical activity exerts a major influence on human metabolism. Physical activity acutely increases glucose uptake, thus lowering circulating blood glucose level. This uptake by contracting skeletal muscles takes place through insulin independent mechanisms [16]. A single exercise bout also induces beneficial metabolic effects after exercise. Muscle insulin sensitivity is increased for up to $48 \mathrm{~h}$ after exercise in healthy individuals [16].

Even relatively low volume of simple physical activity, such as walking or cycling has been shown to induce favorable effects on various metabolic markers in healthy and diseased population. As little as $15 \mathrm{~min}$ of post-meal walking may blunt the glycemic response in healthy women [17] and in women at risk of diabetes [18]. Takaishi et al. found that 6 min of another easily available physical activity, stair climbing and descending sufficed to reduce post-prandial glucose levels in inactive middle aged men with impaired glucose tolerance [19].

The potential of both aerobic and muscle strengthening physical activity to lower postprandial lipidemia is well established [20]. For example, in young healthy participants as little as 3 times 10 min of brisk walking a day reduced triacylglycerol concentration (area under the curve for plasma concentrations) by $16 \%$ [21].

A single bout of physical activity is followed by an acute decrease in blood pressure, known as post-exercise 
hypotension. A current systematic review based on 65 individual studies found that physical activity, regardless of participant and exercise characteristics, leads to a clinically relevant reduction in blood pressure [22].

\section{Acute effects on the immune system}

Inflammatory processes have been linked to chronic diseases with the largest disease burden, such as cardiovascular diseases, type 2 diabetes, cancer, dementia, osteoporosis via irreversible organ damage and dysfunction [23]. A systematic review concludes that a single bout $(30-60 \mathrm{~min})$ of moderate to high intensity physical activity can increase the activity of both circulating IL-6 and neutrophil counts in untrained adults [24].

\section{Acute effects on mental health, wellbeing, mood, sleep and cognition}

As stated above, it is reasonable to expect that the lockdown exerts unfavorable psychological effects on the short and possibly longer term. Because of the well documented acute impact of physical activity on symptoms of psychological distress [25] and potential to increase positive activated affect [26] physical activity should be recommended as a nonpharmacological countermeasure. Beyond improved positive affective physical activity can also promote feelings of vitality [27]. Importantly, even low to moderate volume and low to moderate intensity exercise seems to be beneficial [26]. Indeed as little as 10 min moderate intensity walking can improve mood [28].

Also strong meta-analytic evidence demonstrates the anxiolytic effect of acute relatively short (20 to $30 \mathrm{~min}$ ) activity bouts in adults and older adults [29]. Physical activity, irrespective of intensity and time of day at which activity is performed, can acutely improve various sleep outcomes [29]. Single short (10-20 min) physical activity bouts lead to improved cognition, with most consistent results for domains of executive function [29].

\section{What should we recommend?}

We have shown that on the one hand even short term reduced physical activity may exert harmful effects on physical and mental health and on the other physical activity can acutely counteract exactly these effects. In the following we provide guidance on pragmatic, evidence based physical activity programs that are feasible also under current situations including lockdown.

Whenever and wherever permitted and possible, while complying with local and national regulations, people should be encouraged to be active outdoors, preferably in green areas. As in all other situations, rules of social distancing (at least 1,5-2 $\mathrm{m}$ or six feet) are essential also outdoors. The use of surgical or homemade masks in the community setting has been discussed in a controversial manner. Whereas the Center of Disease Control recommends them [30], the World Health Organization maintains that "the wide use of masks by healthy people in the community setting is not supported by current evidence and carries uncertainties and critical risks" [31]. It has to be considered that masks might impede airflow and therefore provoke discomfort especially with more strenuous exercise. Limited air exchange around the face can lead to a warm, humid microclimate. Mask use and disposal make certain safety measures necessary [31].

Possible outdoor activities include (brisk) walking, jogging and cycling. Green exercise can improve wellbeing [32], and sensible sun exposure might boost the immune system [33]. Novice exercisers should start with low volumes (5-10 min 2-3 times and week) and low intensity (regular speed) and increase both volume and intensity with time. Alternating short periods (e.g. $3 \mathrm{~min}$ ) with lower and higher speeds can enhance health effects and make the workout more enjoyable [7].

If leaving one's house is not permitted, staircases can be used for exercising the lower extremities. Depending on the speed, staircase walking can also function as a cardiovascular exercise. People with compromised balance should hold on to the rails, in this case use of gloves is recommended and washing hands obligatory.

A large number of exercises for improving cardiovascular and muscular fitness, as well as balance can be performed even in very small spaces without devices. Walking in place or around the apartment, jumping and hopping are such options. Similarly to walking outside, volume and intensity should be increased only gradually.

Muscle strengthening exercises can be carried out using elastic bands, if available [34]. If not, exercises, such as sit up, push up, squats etc., all using nothing but one's own body weight, are a perfect option. All these exercises can be modified to accommodate for less well trained or elderly people [35]. Various national and international health and sports agencies provide further ideas and examples of home-based exercises [36].

New evidence suggests that physical activity bouts can be short (also less than $10 \mathrm{~min}$ ) and time spent in activity can be accumulated throughout the week [6]. Starting with shorter bouts and building up activity time gradually might be more accessible for currently inactive people.

To limit adverse events, no physical activity should be performed during acute infection (also other than COVID-19) and in case of absolute contraindications [37]. We do not recommend excessive exercise (high volume high intensity training), since it can lead to transient states of immunodepression and increase of susceptibility to infection [38].

\section{Conclusion}

Lockdown implemented in an attempt to contain the SARS-CoV-2 virus is unprecedented for most Western 
countries, and represents a major societal challenge with conceivable repercussions for people's mental and physical health. Physical activity has the potential to ward off detrimental cardiometabolic effects of inactivity and to strengthen psychological resources and coping skills. Physicians and other health care professionals should use this time as a window of opportunity to provide physical activity counseling to their patients.

\section{Acknowledgments}

Not applicable.

\section{Authors' contributions}

EF conceived of the presented idea, performed the literature review, and wrote the manuscript with substantial intellectual contribution from WB and DAG. WB and DAG revised the manuscript critically for important intellectual content. All authors read and approved the final manuscript.

\section{Funding}

Not applicable.

\section{Availability of data and materials}

All data generated or analyzed during this study are included in this published article.

\section{Ethics approval and consent to participate}

Not applicable.

\section{Consent for publication}

Not applicable.

\section{Competing interests}

The authors declare that they have no competing interests.

\section{Received: 24 April 2020 Accepted: 4 August 2020}

Published online: 12 August 2020

\section{References}

1. Nussbaumer-Streit B, Mayr V, Dobrescu Al, Chapman A, Persad E, Klerings I, et al. Quarantine alone or in combination with other public health measures to control COVID-19: a rapid review. Cochrane Database Syst Rev. 2020:4:CD013574. https://doi.org/10.1002/14651858.CD013574.

2. Tian H, Liu Y, Li Y, Wu C-H, Chen B, Kraemer MUG, et al. An investigation of transmission control measures during the first 50 days of the COVID-19 epidemic in China. Science. 2020. https://doi.org/10.1126/science.abb6105.

3. Kissler SM, Tedijanto C, Goldstein E, Grad YH, Lipsitch M. Projecting the transmission dynamics of SARS-CoV-2 through the postpandemic period. Science. 2020. https://doi.org/10.1126/science.abb5793.

4. Daniel Dunford, Becky Dale, Nassos Stylianou, Ed Lowther, Maryam Ahmed, Irene de la Torre Arenas. Coronavirus: The world in lockdown in maps and charts. 2020. https://www.bbc.com/news/world-52103747.

5. Brooks SK, Webster RK, Smith LE, Woodland L, Wessely S, Greenberg N, Rubin GJ. The psychological impact of quarantine and how to reduce it: rapid review of the evidence. Lancet. 2020;395:912-20. https://doi.org/10. 1016/S0140-6736(20)30460-8.

6. Piercy KL, Troiano RP, Ballard RM, Carlson SA, Fulton JE, Galuska DA, et al. The physical activity guidelines for Americans. JAMA. 2018;320:2020-8. https://doi.org/10.1001/jama.2018.14854.

7. Füzéki E, Banzer W. Physical activity recommendations for health and beyond in currently inactive populations. Int J Environ Res Public Health. 2018. https://doi.org/10.3390/ijerph15051042.

8. Guthold R, Stevens GA, Riley LM, Bull FC. Worldwide trends in insufficient physical activity from 2001 to 2016: a pooled analysis of 358 populationbased surveys with 1.9 million participants. Lancet Glob Health. 2018;6: e1077-86. https://doi.org/10.1016/S2214-109X(18)30357-7.

9. Bowden Davies KA, Pickles S, Sprung VS, Kemp GJ, Alam U, Moore DR, et al. Reduced physical activity in young and older adults: metabolic and musculoskeletal implications. Ther Adv Endocrinol Metab. 2019:10: 2042018819888824. https://doi.org/10.1177/2042018819888824.
10. Oikawa SY, Holloway TM, Phillips SM. The impact of step reduction on muscle health in aging: protein and exercise as countermeasures. Front Nutr. 2019;6:75. https://doi.org/10.3389/fnut.2019.00075.

11. Boyle LJ, Credeur DP, Jenkins NT, Padilla J, Leidy HJ, Thyfault JP, Fadel PJ. Impact of reduced daily physical activity on conduit artery flow-mediated dilation and circulating endothelial microparticles. J Appl Physiol. 2013;115: 1519-25. https://doi.org/10.1152/japplphysiol.00837.2013.

12. Devries MC, Breen L, von Allmen M, MacDonald MJ, Moore DR, Offord EA, et al. Low-load resistance training during step-reduction attenuates declines in muscle mass and strength and enhances anabolic sensitivity in older men. Physiol Rep. 2015. https://doi.org/10.14814/phy2.12493.

13. Saoi M, Li A, McGlory C, Stokes T, von Allmen MT, Phillips SM, Britz-McKibbin P. Metabolic perturbations from step reduction in older persons at risk for sarcopenia: plasma biomarkers of abrupt changes in physical activity. Metabolites. 2019. https://doi.org/10.3390/metabo9070134.

14. Shigdel R, Dalen H, Sui X, Lavie CJ, Wisløff U, Ernstsen L. Cardiorespiratory fitness and the risk of first acute myocardial infarction: the HUNT study. J Am Heart Assoc. 2019;8:e010293. https://doi.org/10.1161/JAHA.118.010293.

15. Hooker SP, Sui X, Colabianchi N, Vena J, Laditka J, LaMonte MJ, Blair SN. Cardiorespiratory fitness as a predictor of fatal and nonfatal stroke in asymptomatic women and men. Stroke. 2008;39:2950-7. https://doi.org/10. 1161/STROKEAHA.107.495275.

16. Sylow L, Richter EA. Current advances in our understanding of exercise as medicine in metabolic disease. Curr Opin Physiol. 2019;12:12-9. https://doi. org/10.1016/j.cophys.2019.04.008.

17. Nygaard H, Tomten SE, Høstmark AT. Slow postmeal walking reduces postprandial glycemia in middle-aged women. Appl Physiol Nutr Metab. 2009;34:1087-92. https://doi.org/10.1139/H09-110.

18. Lunde MSH, Hjellset VT, Høstmark AT. Slow post meal walking reduces the blood glucose response: an exploratory study in female Pakistani immigrants. J Immigr Minor Health. 2012;14:816-22. https://doi.org/10.1007/ s10903-012-9574-x

19. Takaishi T, Imaeda K, Tanaka T, Moritani T, Hayashi T. A short bout of stair climbing-descending exercise attenuates postprandial hyperglycemia in middle-aged males with impaired glucose tolerance. Appl Physiol Nutr Metab. 2012:37:193-6. https://doi.org/10.1139/h11-140.

20. Peddie MC, Rehrer NJ, Perry TL. Physical activity and postprandial lipidemia: are energy expenditure and lipoprotein lipase activity the real modulators of the positive effect? Prog Lipid Res. 2012;51:11-22. https://doi.org/10. 1016/j.plipres.2011.11.002.

21. Miyashita M, Burns SF, Stensel DJ. Accumulating short bouts of brisk walking reduces postprandial plasma triacylglycerol concentrations and resting blood pressure in healthy young men. Am J Clin Nutr. 2008;88:122531. https://doi.org/10.3945/ajen.2008.26493.

22. Carpio-Rivera E, Moncada-Jiménez J, Salazar-Rojas W, Solera-Herrera A Acute effects of exercise on blood pressure: a meta-analytic investigation. Arq Bras Cardiol. 2016;106:422-33. https://doi.org/10.5935/abc.20160064.

23. Suzuki K. Chronic inflammation as an immunological abnormality and effectiveness of exercise. Biomolecules. 2019. https://doi.org/10.3390/ biom9060223.

24. Brown WMC, Davison GW, McClean CM, Murphy MH. A systematic review of the acute effects of exercise on immune and inflammatory indices in untrained adults. Sports Med Open. 2015;1:35. https://doi.org/10.1186/ s40798-015-0032-X.

25. Elkington TJ, Cassar S, Nelson AR, Levinger I. Psychological responses to acute aerobic, resistance, or combined exercise in healthy and overweight individuals: a systematic review. Clin Med Insights Cardiol. 2017;11: 1179546817701725. https://doi.org/10.1177/1179546817701725.

26. Reed J, Ones DS. The effect of acute aerobic exercise on positive activated affect: a meta-analysis. Psychol Sport Exerc. 2006;7:477-514. https://doi.org/ 10.1016/j.psychsport.2005.11.003.

27. Liao Y, Shonkoff ET, Dunton GF. The acute relationships between affect, physical feeling states, and physical activity in daily life: a review of current evidence. Front Psychol. 2015;6:1975. https://doi.org/10.3389/fpsyg.2015.01975.

28. Crush EA, Frith E, Loprinzi PD. Experimental effects of acute exercise duration and exercise recovery on mood state. J Affect Disord. 2018;229: 282-7. https://doi.org/10.1016/j.jad.2017.12.092.

29. 2018 Physical Activity Guidelines Advisory Committee. 2018 Physical Activity Guidelines Advisory Committee Scientific Report. 2018. https://health.gov/ sites/default/files/2019-09/PAG_Advisory_Committee_Report.pdf. Accessed 14 Apr 2020. 
30. Center of Disease Control. Use of Cloth Face Coverings to Help Slow the Spread of COVID-19. 2020. https://www.cdc.gov/coronavirus/2019-ncov/ downloads/DIY-cloth-face-covering-instructions.pdf. Accessed 15 Apr 2020.

31. World Health Organization. Advice on the use of masks in the context of COVID-19. 2020. https://www.who.int/publications-detail/advice-onthe-use-of-masks-in-the-community-during-home-care-and-in-healthcaresettings-in-the-context-of-the-novel-coronavirus-(2019-ncov)-outbreak. Accessed 15 Apr 2020.

32. Rogerson M, Wood C, Pretty J, Schoenmakers P, Bloomfield D, Barton J. Regular doses of nature: the efficacy of green exercise interventions for mental wellbeing. Int J Environ Res Public Health. 2020. https://doi.org/10. 3390/ijerph17051526.

33. Holick MF. Biological effects of sunlight, ultraviolet radiation, visible light, infrared radiation and vitamin D for health. Anticancer Res. 2016;36:1345-56.

34. Füzéki E. Muskelkräftigung mit elastischen Bändern. Zbl Arbeitsmed. 2019; 152:440. https://doi.org/10.1007/s40664-019-00364-8.

35. National Heath Service. Exercises for older people. 2020. https://www.nhs. uk/livewell/fitness/documents/NHS_strength_exercise.pdf.

36. World Health Organization Regional Office for Europe. Stay physically active during self-quarantine. http://www.euro.who.int/en/health-topics/ health-emergencies/coronavirus-covid-19/novel-coronavirus-2019-ncovtechnical-guidance/stay-physically-active-during-self-quarantine. Accessed 14 Apr 2020

37. Riebe D, Franklin BA, Thompson PD, Garber CE, Whitfield GP, Magal M, Pescatello LS. Updating ACSM's recommendations for exercise preparticipation health screening. Med Sci Sports Exerc. 2015;47:2473-9. https://doi.org/10.1249/MSS.0000000000000664.

38. Nieman DC. Exercise, infection, and immunity. Int J Sports Med. 1994; 15(Suppl 3):S131-41. https://doi.org/10.1055/s-2007-1021128.

\section{Publisher's Note}

Springer Nature remains neutral with regard to jurisdictional claims in published maps and institutional affiliations.

Ready to submit your research? Choose BMC and benefit from:

- fast, convenient online submission

- thorough peer review by experienced researchers in your field

- rapid publication on acceptance

- support for research data, including large and complex data types

- gold Open Access which fosters wider collaboration and increased citations

- maximum visibility for your research: over $100 \mathrm{M}$ website views per year

At $\mathrm{BMC}$, research is always in progress.

Learn more biomedcentral.com/submissions 